\title{
ILCEA
}

Revue de l'Institut des langues et cultures

d'Europe, Amérique, Afrique, Asie et Australie

$31 \mid 2018$

Récits fictionnels et non fictionnels liés à des

communautés professionnelles et à des groupes spécialisés

\section{The Stories Journalists Tell: A Study of Narrative Modes in the US Press Relating to the 2016 Rio}

\section{Games}

Les récits des journalistes : analyse des modes de narration dans la presse des

États-Unis à propos des Jeux Olympiques de Rio

\section{Caroline Peynaud}

\section{CpenEdition}

\section{Journals}

\section{Electronic version}

URL: http://journals.openedition.org/ilcea/4682

DOI: $10.4000 /$ ilcea.4682

ISSN: 2101-0609

\section{Publisher}

UGA Éditions/Université Grenoble Alpes

Printed version

ISBN: 978-2-37747-043-3

ISSN: 1639-6073

\section{Electronic reference}

Caroline Peynaud, «The Stories Journalists Tell: A Study of Narrative Modes in the US Press Relating to the 2016 Rio Games », ILCEA [Online], 31 | 2018, Online since 06 March 2018, connection on 19 April 2019. URL : http://journals.openedition.org/ilcea/4682 ; DOI : 10.4000/ilcea.4682

This text was automatically generated on 19 April 2019

(C) ILCEA 


\section{The Stories Journalists Tell: A Study of Narrative Modes in the US Press Relating to the 2016 Rio Games}

Les récits des journalistes : analyse des modes de narration dans la presse des États-Unis à propos des Jeux Olympiques de Rio

Caroline Peynaud

\section{Introduction}

1 In dealing with the non-fictional narratives journalists produce, the question of ethics rapidly appears as a central issue. The link between the two notions was naturally raised in an interview carried out with a teacher from the City University of New York School of Journalism (26/04/12):

Question: What are the main ethical principles?

Answer: Well, the main principles are do not add, do not twist, verify the truth. [...]

I could show you sentences that describe things that didn't happen, sentences that the editor wrote. That's possible because there are a lot of grey areas in ethics. And of course, because objectivity is not possible, of course, it's not possible! [...] Only by telling the story, you change it.

Journalists themselves point out to "a writer's paradox" according to which telling a story changes the story. However, telling stories is at the very heart of the journalist's work, as Ramonet explains:

Journalism does not only consist in giving statistics, figures, facts, but rather in elaborating and building, from such raw material, a narrative filled with all the ingredients-lexical, rhetorical, dramatic-of great stories. $(2011: 130)^{1}$

Telling stories also means attracting readers, an essential function in an industry that is struggling economically. The press must constantly find a balance between the ethical constraint of conveying as unbiased information as possible and using discursive means to convey the information to the audience, which inevitably means expressing a point of 
view on the events. Studying narrative modes in press articles reveals how journalists seek compromise between these two contradictory injunctions.

The main difficulty in studying narration in press articles lies in the fact that narrative markers do not constitute a formal list that would define how to identify a narrative text. On the contrary, an infinity of markers may be taken into account, the choice of which depends on the type of text under study and on the knowledge one may have of the authors' concerns. That is why a certain knowledge of the domain of journalism is essential to identify the relevant narrative modes in a specific text. News discourse is studied here following a socio-cultural approach to ESP studies, that is to say as "a specialised variety of English" (SVE) in which culture, history and values intersect with how the discourse is built (Resche, 2013), as part 1 will show. The following sections focus on how narration is used in the press and the functions it assumes.

\section{Analysing narration in a press corpus}

\subsection{Context: Journalism as a specialised variety of English}

5 The present study is part of a wider research project concerning journalism in the United States considered as a specialised variety of English, which Resche describes as follows (2013):

Since any specialized discipline or professional field is based on theory or practice that are expressed through language, language can serve as a starting point for further investigation into specific domains and specialized communities, and into their culture and discourse. (2013: 14)

6 We consider that culture and discourse are related and understanding the professional culture of the domain under study cannot be dispensed with in the study of discourse, in line with the sociocultural approach advocated by Belcher (2004).

7 In this context, it should be pointed out that the professional community of journalists is here analysed as a homogeneous community since the values shared are similar for all news media, as seen in the numerous injunctions published by media associations to which most written media belong (Peynaud, 2013: 230). Belonging to these associations and adopting their ethical principles is a way for newspapers to convince readers to trust them and so to buy them. It does not mean, however, that all publications comply with these rules strictly, and it is clear that they often abide by these principles to varying degrees. The homogeneity of this professional community is also underlined by Russo: "Journalists identify themselves more easily with the profession of journalism than for example with the medium or media company that employs them." (1998: 74). Journalists are here considered to have a strong, unifying culture that helps create a stable professional community.

8 To understand this professional community, a field study was carried out in New York in 2012, during which journalists were interviewed on various topics, including their opinion on the injunctions to relate only facts. A number of their answers shed light on how they consider narration, a term we will now attempt to define in more detail. 


\subsection{Journalist attitudes towards narration}

9 A story can be broadly characterised as a succession of events with a beginning and an end. Genette (1966: 152) defines a narrative as the representation of a sequence of events, real or fictional, through language, and more specifically through written language. Thus a story is a "representation" of events, a reconstruction of reality whose purpose is to make sense of events. More specifically, for Sartre (1947: 147), a story must have causal links which explain events instead of merely relating them as a chronological succession. Telling a story is thus about reconstructing reality, about going beyond the mere observation of facts (Barthes, 1966: 26). Narrators are central to this process, since it is they who take charge of reconstructing reality. Narrators build the story, according to their point of view, through a process of selection of events and according to their own interpretation of the facts, what Genette calls the narrator's "perspective" (2007: 190), the choice of a narrative point of view.

The journalist's concept of narration must be analysed with regard to this definition. The term "story" is frequently used by journalists in a sense specific to the field in phrases such as "cover a story", "publish a story", "work on a story", "getting the story right", etc., in which the term may refer to the events, the article once it is written, the process of writing, or the facts stated in the article. The term "story" appeared in the field of journalism at the end of the $19^{\text {th }}$ century, when objectivity became one of the main ethical values of the profession. It replaced the term "column", which had previously been used for all types of articles and which subsequently came to refer to articles which expressed an opinion while "story" was used for articles that tended towards neutrality (Peynaud, 2015: 36). At the time, news articles also evolved from a chronological structure to the inverted pyramid structure, which appeared to be more factual and served the new objectivity values better (Hartsock, 2007: 266) or, as Kramer explains:

The bureaucratic "report" tone springs from a wholesome tradition-that the press has a vested duty to guard the population. Reporters and editors have serious business to pursue, and that mindset is reflected in the official edge to the newspaper voice. (2000: 6)

The term "story" is thus associated with straight facts and neutrality and reflects the rejection of storytelling as it exists outside the field of journalism (Roeh, 1989: 162). The journalist's discourse thus reflects what has been termed a "rhetoric of objectivity", based on the notion that language should be as factual and neutral as possible (ibid.).

However, some authors point out that narration has recently been making a return to journalism, with Pulitzer prizes awarded to narrative journalism (Hartsock, 2007: 268), with more and more newspapers publishing narrative series (Kramer, 2000: 4) and an increasing number of journalists following narrative journalism courses (ibid.).

13 This form of journalism, called "literary journalism" (Hartsock, 2007: 258) or "narrative journalism" (Johnston \& Graham, 2012: 518), is inspired by the "new journalism" of the 1960s, whose style was inspired by literature, cinema, music and poetry (Pelissier \& Eyriès, 2014: 8). However, according to these authors (ibid.: 11), whereas the latter borrows heavily from fictional artefacts, narrative journalism relies on facts and in-depth research, even immersion in the events, creating what they termed "reality-based fictions" (ibid:: 26). ${ }^{2}$ 
According to Neveu (2014: 536), narrative journalism represents the core of journalism work insofar as it is based on "leg-work" and in-depth research, as opposed to the "seated journalism" that prevails in today's newsrooms (ibid.: 534). While many newspapers experience declining readership, narrative journalism is generally considered as more engaging than traditional journalism (Kramer, 2000: 8), the added "personality" of the articles (Neveu, 2015: 539) being more likely to attract readers. As Neveu points out, "The use of narratives, the art of storytelling, are not sins or treasons for journalistic practice. Writing or telling seamless, attractive and illuminating stories is a core skill to transform facts into news" (ibid.: 536).

However, this evolution represents a profound cultural change for today's journalists, who were trained to be concise and factual (Hartsock, 2007: 258; Pelissier \& Eyriès, 2014: 18). Although some periodicals such as The New Yorker specialise in this sort of journalism, it is not universally adopted. Though narrative journalism as such does not constitute the focus of the present study, several authors nevertheless highlight the fact that narration, being increasingly widely accepted in newsrooms, is to be found in all types of articles (Johnson \& Graham, 2012: 522; Kramer, 2000: 5).

Following these conclusions, the purpose of the present study is to identify the traces of narration that may be found in a random selection of articles. Studying how narration is constructed in news articles reveals how journalists seek compromise between these contradictory injunctions, that is to say how they make their stories about news events fit the news format.

\subsection{Narration in discourse: narrative modes}

17 The notion of narration encompasses a great variety of discursive markers. The first difficulty is then to determine how to recognise narration in discourse. Indeed, according to Revaz (2009) and Adam (2011), there are no specific narration markers, since narration lies in the construction of the discourse and in its content rather than in specific discursive features. Table 1 shows how the two authors define narrative content from a discourse analysis point of view:

Table 1. - Comparison of components of narrative discourse

\begin{tabular}{|c|c|}
\hline Adam (2011: 6) & Revaz (2009: 100) \\
\hline $\begin{array}{l}\text { - a succession of events } \\
\text { - a thematic unity } \\
\text { - transformed predicates } \\
\text { - action unity } \\
\text { - narrative causality and plot } \\
\text { construction } \\
\text { - final evaluation }\end{array}$ & $\begin{array}{l}\text { - a representation of actions } \\
\text { - chronological unfolding } \\
\text { - a transformation between the initial and the final } \\
\text { state } \\
\text { - causal sequence / chain } \\
\text { - an unusual or unpredictable development of } \\
\text { actions }\end{array}$ \\
\hline
\end{tabular}

ADAPTED FROM ADAM (2011) AND REVAZ (2009)

Revaz (ibid.: 104) also points out that there may be several degrees of narration depending on whether there are causal links or not, the structure of the text and especially on 
whether there is a real plot. Table 2 summarises these variations according to three main categories, chronicles, accounts and stories:

Table 2. - Variations according to category of narrative texts

\begin{tabular}{|l|l|l|l|}
\hline & Chronicle & Account & \multicolumn{1}{|c|}{ Story } \\
\hline Representation & & Actions or events & \\
\hline Temporality & & Consecutiveness & \\
\hline Causality & & Consequence \\
\hline Composition & & \multicolumn{3}{|l}{ Plot, climax, resolution } \\
\hline
\end{tabular}

ADAPTED FROM REVAZ (2009)

19 According to Revaz, each text category is marked by specificities in terms of representation, temporality, causality and composition. All three categories represent actions or events in the mode of consecutiveness. Both accounts and stories are characterised by the expression of causality in terms of consequence, but only stories have a plot, a climax and a resolution.

20 A number of conclusions may be drawn from these analyses. First, it is clear that there should always be temporal cohesion in a narrative. Adam mentions a "succession of events" while Revaz cites "chronological unfolding". However, causal cohesion determines the degree of narration to which a text belongs. While these authors talk about "narrative causality" or "causal sequence / chain", Revaz's categories suggest that "consequence" is only found in accounts and stories, not in chronicles. Focusing on causality thus excludes certain narrative texts de facto, while focusing on temporality includes more types of texts.

21 Narratives must also contain an unpredictable development of events, leading to an unexpected ending. In this context, Revaz evokes "an unusual or unpredictable development of actions". However, it is not easy to determine whether press articles do have an ending at all. Indeed, Revaz (ibid.) dedicates a chapter to "media series", defined as successive articles bearing upon a single event that unfolds over several days, in which she discusses whether media series may be considered a narrative genre. She concludes that such series contain a plot, built through anticipation and characterised by nonresolution, which makes the story open and more dynamic than typical narratives. However, she also points out that journalists tend to lack distance, and that these articles have no coherence or ending, since the event is told as it unfolds.

22 Hence, although news stories are not typical narratives, whether they contain any features of a narrative text, or whether they correspond to any of the types of narratives identified by Revaz, remains to be determined. To do so, we need to discuss the elements of narration specifically relevant to news discourse. 


\subsection{Corpus analysis} the summer of 2016. The corpus contains 52 news articles (a total of 35,000 words) which were published in a number of newspapers of both general and special interest, such as The New York Times, USA Today, for example, defined by Laffont and Petit (2007) as publications addressed to the general public, but focusing on particular areas of interest (cinema, gardening or, here, sports). All the articles selected for the corpus are thus addressed to the general public. The fact of choosing a single topic as the Rio Games makes comparisons easier since only a limited number of topics is analysed in the corpus. The corpus falls into three principal genres:

- Hard news articles, in which the events are told factually (henceforth referred to as HNA). HNAs are subjected to strict organisational rules, such as the classic inverted pyramid structure, in which the main elements of the story are presented at the beginning of the article and then gradually developed throughout the text (Ellis, 2001: 127).

- Feature articles (henceforth referred to as FA), especially represented by the sub-genre of portraits in the corpus. Although the inverted pyramid structure is sometimes found in FAs, lexical and compositional creativity is encouraged and description is allowed, with an increased presence of adjectives compared to HNAs (ibid.).

- Opinion pieces, marked by the journalist's opinion, usually expressed in the first person. (These have been excluded from the present study because they are not what is usually termed as "stories", as explained in section 1.2.) ${ }^{3}$

As discussed in the previous section, narration is defined as a certain content rather than as the presence of specific markers. Based on the above definitions, it would appear that cohesion is an essential element of narration. The main questions here are then: What makes news articles cohesive? How can their cohesion be defined? Does their specific type of cohesion make these texts narrative in nature?

first element that was taken into account is the structure of the articles, to determine whether there were chronological or causal links and what cohesion may be based upon. Ledes (the introductory section of a news story intended to entice the reader to read the full story) and endings were especially analysed in this perspective.

Narrative sequences, defined as the combination of time markers and past tenses, were then studied, first to determine how successive narrative sequences are organised within an article, and then to understand how narration is expressed within short narrative sequences.

\section{Narration in the structure of the articles}

\subsection{Ledes and endings: is there a transformation between the initial and the final state?}

Since narration is, in part, a matter of structure, studying the progression of action in the articles reveals to what extent their general structure may be defined as narrative. Progression in the articles can be seen through the evolution between the lede and the ending. Although ledes in HNA need to respect a clear format (and answer the questions:

ILCEA, 31 | 2018 
who what when where why), ledes in FA may be more creative, according to the paper's newswriting guidelines (Ellis, 2001: 85). The content of ledes and endings was analysed manually to determine the progression between the lede and the ending.

A clear progression appears in feature articles. Most articles in the FA corpus belong to the sub-genre of portraits. Since what makes a portrait interesting is the process by which the person who is the focus of the portrait reached his or her current position, obvious paths are of little interest to readers. This is the most common situation for FAs, as examples (1) and (2) illustrate:

(1): $\mathrm{F} 4^{4}$

Lede: Alicen Diane Warren should be a ghost competing in the Special Olympics this weekend. She was born on Feb. 21, 1998, and took her first breath in frantic survival mode.

Ending: Alicen Diane Warren is going to fly, soaring like a bumblebee, defying physics, defying odds and, most important, paying no attention to anyone telling her what she can't do.

(2): F2

Lede: There was Jim Craig on the ice, the epitome of Americana. The fresh-faced college boy, just 22, wearing a U.S. flag and looking in the stands for his beloved dad.

Ending: Craig, who had a short career in professional hockey, is a motivational speaker, according to his Twitter page.

In example (1), there is a clear positively evaluated evolution from "frantic survival mode" to "soaring like a bumblebee", while in example (2), the transformation is negatively evaluated between "the epitome of Americana" and "a short career in professional hockey" / "a motivational speaker". However, in a narrative, the transformation also needs to be unexpected, which is not the case in these articles. Examples (1b) and (2b) below show that the headlines of the articles had already announced the transformation making it unlikely that a reader having read the headline would be surprised by the ending of the article:

(1b) F4: Special Olympics competitor finds light in darkness

(2b) F2: Olympics hero Craig to auction 'Miracle on Ice' gold medal

The headline in (1b) announces that the person the portrait focuses on is an Olympic competitor thus making it clear from the beginning what the health issues pointed to will lead to. In (2b), the headline announces that the athlete will "auction [...] his medal", suggesting that he has moved on from that time in his life. In both cases, after reading the headline, readers are likely to be more surprised by the lede, describing the point of departure of the person's evolution, than by the ending. In this sense, there is no suspense in the articles, since, even though there is a transformation, all the elements of the transformation are presented from the very beginning.

In HNAs, in contrast, there is usually no change of state at all. The progression of the article is based more on an elaboration of the original fact stated in the headline and in the lede. Table 3 shows three examples of ledes and endings from HNA articles. 
Table 3. - Ledes and endings in HN

\begin{tabular}{|l|l|l|l|}
\hline (3) HN11 & $\begin{array}{l}\text { Despite increasing worries about the Zika } \\
\text { outbreak, an international health official } \\
\text { says the 2016 Summer Olympics should not } \\
\text { be postponed, canceled or moved from Rio } \\
\text { (e Janeiro. }\end{array}$ & $\begin{array}{l}\text { Zika has been reported in 58 countries, } \\
\text { primarily in Central and South } \\
\text { America, the organization said. }\end{array}$ \\
\hline (4) & $\begin{array}{l}\text { According to Moody's, the upcoming } \\
\text { summer Olympics will give Rio de Janeiro } \\
\text { an economic boost, however will not solve } \\
\text { the country's deepening economic slump. }\end{array}$ & $\begin{array}{l}\text { The opening ceremony of the 2016 } \\
\text { tammer Olympic Games is scheduled to } \\
\text { of world leaders are expected to attend } \\
\text { the event. }\end{array}$ \\
\hline (5) & $\begin{array}{l}\text { HN27 } \\
\text { On Sunday, Fouad Baka of Algeria finished } \\
\text { a 1500-meter race in just 3 minutes and } \\
49.59 \text { seconds at Maracanã Stadium in Rio } \\
\text { de Janeiro. }\end{array}$ & $\begin{array}{l}\text { "It wasn't easy to get this gold medal," } \\
\text { Abdellatif said afterward. "I've been } \\
\text { working one or two years nonstop and } \\
\text { it's been very, very hard for me." }\end{array}$ \\
\hline
\end{tabular}

These are examples of elaboration, a term used when the ending gives more details about the initial situation. It is the principle behind the "inverted pyramid" structure. This does not apply to HNAs only since some FAs also follow this principle:

(6): F7

Lede: Under the bright lights of Times Square, Adeline Gray grabbed the microphone and turned an interview into an impromptu speech about the virtues of wrestling.

Ending: And I think that's something that girls are drawn to. They realize how important confidence is in so many areas of their lives.

In these cases, the ending provides an explanation for the initial situation described in the lede-just as the rest of the article, it only elaborates on the content of the lede.

\subsection{Types of endings}

This preliminary analysis shows that there are several types of endings in the corpus articles. Endings were characterised according to their content and two main types of endings were found in both HNAs and FAs: factual and open endings.

Factual endings only provide further facts about the situation, as is the case in example (3), while open endings contain a reference to possible future events, thus underscoring the non-resolution Revaz (2009) talks about. Open endings typically contain modals (especially "will"), present tense, conditionals, time markers referring to the present (such as "now") or phrases such as "it is possible that", that hint at future developments, as examples (7) and (8) illustrate:

(7): F6

It will be very high up," if he wins a medal, Garcia said. "It will be right up there with the Ryder Cups, with a major if I win one, with The Players Championship I won. It would be great. ${ }^{5}$

(8): HN14

The U.S. women, however, must wait until June 24 for the final boat lineups to be 
named. With the women still battling for seats in their respective boats, it's possible not all 13 Huskies will end up competing in Rio. quantitative results:

Table 4. - Quantitative analysis of open and factual endings in FAs and HNAs narration may take place at a lower discursive level, namely the level of the sequence. Narrative sequences were identified in the corpus, based upon the combination of time markers and past tenses (Adam, 2011: 101). Example (9) illustrates the sort of narrative sequences that were taken into account:

(9): F14

Then the whispers started, "It's Simone! It's Simone Biles! Oh, I love her!" Smartphones came out to snap pictures of the Olympic gymnastics champion, and at first a trickle, then a flood surged forward to ask for selfies with the gold medalist, the modern version of autograph hunting.

Example (9) has three time markers indicating the succession of the events (underlined) and three action verbs in the simple past (bold type). For the purpose of this study, the following time markers were selected and identified in the corpus: first, then, after, before, when, as soon as and while. We need, however, to keep in mind that "first" and "then" are often used to situate the story rather than build it, as example (10) illustrates:

(10): HN9

The first medal events begin a day later and will include fencing. 
In this example, "first" cannot be considered a marker of narration since it is not related to action verbs. It was thus considered that narrative sequences were those sequences that combined at least one time marker with at least one action verb in a past tense. A cofrequency search with the help of TXM software, made it possible to isolate such associations of time markers with verbs in the past. Table 5 presents the statistical data obtained.

Table 5. - Co-frequency of time markers and verbs in the past in TXM

\begin{tabular}{|c|c|c|}
\hline Time Marker & Verb & $\begin{array}{l}\text { Number of } \\
\text { co-occurrences }\end{array}$ \\
\hline first & $\begin{array}{l}\text { announced } \\
\text { became } \\
\text { came } \\
\text { said } \\
\text { took } \\
\text { wanted } \\
\text { won }\end{array}$ & $\begin{array}{l}2 \\
4 \\
3 \\
6 \\
3 \\
2 \\
6\end{array}$ \\
\hline then & $\varnothing$ & \\
\hline after & $\begin{array}{l}\text { began } \\
\text { took } \\
\text { lost } \\
\text { made } \\
\text { said } \\
\text { told }\end{array}$ & $\begin{array}{l}2 \\
3 \\
2 \\
2 \\
8 \\
2\end{array}$ \\
\hline before & $\begin{array}{l}\text { said } \\
\text { told }\end{array}$ & $\begin{array}{l}2 \\
2\end{array}$ \\
\hline when & $\begin{array}{l}\text { came } \\
\text { wanted } \\
\text { got } \\
\text { said } \\
\text { won }\end{array}$ & $\begin{array}{l}2 \\
2 \\
2 \\
6 \\
2\end{array}$ \\
\hline as soon as & $\varnothing$ & \\
\hline while & $\begin{array}{l}\text { gave } \\
\text { said } \\
\text { went }\end{array}$ & $\begin{array}{l}2 \\
2 \\
3\end{array}$ \\
\hline
\end{tabular}

In view of these results, sentences containing then and as soon as were not taken into account, since these markers are never associated with past verbs in the corpus. We now 
move on to analyse the link between narrative sequences in an article and then discuss the way narration is built within the sequences.

\subsection{Jumbled chronology}

The main question this section seeks to answer is how successive narrative sequences, as defined in the previous section, are linked in the articles and whether the structure built using these sequences may be defined as narrative, with events unfolding chronologically. It appears that it is not the case in our corpus, where articles alternate paragraphs in the past with paragraphs in the present or the future. Moreover, not all narrative sequences in a single article refer to the same period of time in the past, just as sequences about the future may refer to various future events and moments.

Table 6 presents progression in HN1, a hard news article whose tense structure is typical of the structure generally found in the corpus articles, where the chronology is jumbled. ${ }^{6}$ Taking as a point of reference the main event described in the article (T), which is in the past, all other events are described as $\mathrm{T}+(\mathrm{N})$ if they are situated after the main event, or T(N) if they occurred before.

What first appears is that the same period of time is rarely referred to twice in the article, with the exception of $\mathrm{T}+2$, which refers to the Olympic Games, and $\mathrm{T}$, the main event concerning the robbery members of the Spanish sailing team were victims of in Rio, mentioned once at the beginning of the article and once at the end. Other narrative sequences refer to what happened immediately before the robbery (T-1) and to several short narrative sequences (T-2 and T-3) describing similar events that occurred in the more or less distant past. The two following descriptive sequences refer to two different situations, since the first one describes violence in Brazil in general, and the second the various security difficulties athletes were likely to encounter during the Olympic Games. Thus, if there are several narrative sequences present in the article, they nevertheless refer to varying periods of time and do not construct a consistent story, made of successive events occurring at a certain period of time. On the contrary, the short narrative sequences that compose the article are generally unrelated in this respect.

Consistency in this article derives from the fact that all narrative and descriptive sequences are linked to the main event since they explain its causes and its consequences, or compare it to similar past events. This type of composition, in keeping with the inverted pyramid structure, frowns upon relating events chronologically, recommending instead that they be related as a development of the main event of the article.

Additionally, a higher number of words is dedicated to future events (593 words) than to past events ( 350 words) or to descriptions of the present situation ( 219 words), with generally longer sequences dedicated to the future and the article ending on a $\mathrm{T}+2$ sequence. Future events represent $51 \%$ of the article, which clearly indicates the general orientation of the article, whose main purpose is not to tell a story that has already taken place, but to predict an event to come.

Table 6. - Analysis of the progression of events in HN1

\begin{tabular}{|l|l|l|}
\hline Section introduction & $\begin{array}{l}\text { Nbr of } \\
\text { words }\end{array}$ & $\begin{array}{l}\text { Characterisation of } \\
\text { section }\end{array}$ \\
\hline
\end{tabular}




\begin{tabular}{|c|c|c|}
\hline $\begin{array}{l}\text { Fernando Echavarri and two other members of the } \\
\text { Spanish sailing team were robbed at gunpoint. }\end{array}$ & 40 & $\begin{array}{l}\text { Presentation of the main } \\
\text { event }(T)\end{array}$ \\
\hline $\begin{array}{l}\text { Echavarri and his teammates were headed to Rio's Santa } \\
\text { Teresa neighbourhood }\end{array}$ & 53 & T-1 (Immediate past event) \\
\hline Come August, street crime may present a greater threat & 23 & T-2 (Future event) \\
\hline $\begin{array}{l}\text { Brazil has some of the highest violent crime rates in the } \\
\text { world. }\end{array}$ & 53 & Descriptive \\
\hline $\begin{array}{l}\text { On May 7, a 17-year-old girl, Ana Beatriz Pereira Frade, } \\
\text { was slain }\end{array}$ & 166 & $\begin{array}{l}\text { T-2 (Three narrative } \\
\text { sequences about past } \\
\text { events) }\end{array}$ \\
\hline Zika is one of many safety and security concerns & 93 & Descriptive \\
\hline $\begin{array}{l}\text { But Brazil will be throwing considerably less money at } \\
\text { the problem than originally planned }\end{array}$ & 271 & $\mathrm{~T}+1$ (Future event) \\
\hline $\begin{array}{l}\text { The need to be careful and the need for more policing in } \\
\text { Rio are nothing new }\end{array}$ & 107 & $\begin{array}{l}\text { T-3 (Two unrelated } \\
\text { sequences about past } \\
\text { events) }\end{array}$ \\
\hline $\begin{array}{l}\text { This summer, the Olympic family will be the best } \\
\text { protected. }\end{array}$ & 42 & $\mathrm{~T}+2$ (Future event) \\
\hline $\begin{array}{l}\text { Consider that the legacy of the } 1972 \text { Munich Olympic } \\
\text { massacre }\end{array}$ & 24 & T-4 (Past event) \\
\hline As Kayyem pointed out, & 118 & $\mathrm{~T}+1$ (Future event) \\
\hline ‘We made a big mistake,' Echavarri conceded. & 33 & $\mathrm{~T}$ \\
\hline $\begin{array}{l}\text { Heeding the advice of Echavarri, sailors and sailing fans } \\
\text { probably won't stroll between Guanabara Bay and the } \\
\text { boutique hotels and restaurants of Santa Teresa. }\end{array}$ & 139 & $\mathrm{~T}+2$ (Future event) \\
\hline
\end{tabular}

However, this type of construction cannot be accounted for by the simple obligation to follow the inverted pyramid structure. Indeed, even in features, where the inverted pyramid is not mandatory, the same jumbled chronology appears. Features generally present greater consistency in the tenses used, but the events are still not related in the order in which they occurred. We cannot, therefore, consider that there is a chronological development.

On the other hand, this analysis has revealed that the progression is usually of a circular nature, with the content of the headline and the lede generally repeated in the ending. The progression is also based on topical rather than temporal cohesion since the articles develop what is presented in the lede and evolve through successive characterisations of the main topic, whether a person or an event. In this sense, since each element develops the main topic of the story, leading to the final conclusion, the articles tend to be 
organised like descriptions rather than like narratives. According to Adam (2011), descriptive sequences can be recognised through the fact that they answer the question "how?", which seems to be the case for the structure described above, although this hypothesis would require further investigation. What is, however, clear is that cohesion does not rely on a chronological structure.

Nevertheless, even though several narrative sequences do not necessarily form a consistent narrative, focusing on the narrative sequences themselves reveals that features of narration are present in the articles.

\subsection{Narrative sequences and the role of time markers}

The final level of analysis concerns the short narrative sequences themselves and the information they contain. These sequences are structured by time markers and action verbs, as mentioned in 3.1. This section gives a qualitative analysis of the quantitative results given in 3.1. At this finer level of analysis, the way narration is used in the press truly emerges. Table 7 illustrates some uses of time markers found in the corpus, with times markers indicated in bold.

Table 7. - Uses of time markers in the corpus

\begin{tabular}{|l|l|l|}
\hline (11) & F2 & After that 4-2 win, Craig was handed a flag by a U.S. official \\
\hline (12) & HN6 & Willis, discussing the issue after a workout at the UM track last weekend, [...] \\
\hline (13) & F12 & $\begin{array}{l}\text { "I never knew anything about open water swimming before one year ago and now I } \\
\text { do, Kromowidjojo told reporters at the European championships on Thursday, a } \\
\text { day after she took silver in the } 100 \text { meters freestyle in } 53.24 \text { seconds. }\end{array}$ \\
\hline (14) & HN9 & $\begin{array}{l}\text { When asked about the seeming contradiction of canceling a camp in Puerto Rico } \\
\text { because of Zika but going on to compete in the country hardest hit by the virus, } \\
\text { Bowman said he believes the risk will actually be much lower at the Olympics. }\end{array}$ \\
\hline
\end{tabular}

The examples in Table 7 illustrate an apparently characteristic feature of how narration is created in the corpus. In these examples, time markers are either prepositions $(11,12)$ or they introduce a subordinate clause $(13,14)$. In both cases, the information presented in the clause containing the time marker contains narration, since they describe events in the past and situate them in relation to the main clauses.

What is interesting is the fact that this information is presented in the form of subordinate clauses or prepositional clauses. Indeed, information in such clauses is generally considered as "old" information (Loock, 2007: 338), or "given" information the addressee should already know about, as opposed to the main clause containing the "new" information the article focuses on. However, since press readership is varied and unstable (Peynaud, 2013: 156) information cannot be considered as "new" or "old" based on presumed objective knowledge of the readers. What this structure of information signifies is that the specifically narrative parts of the discourse are not the main point of the article, not what journalists wish their readers to focus on. 
Example (11) illustrates this process very clearly. The article, already mentioned in examples (2) and (2b), informs the reader about the life of Jim Craig, characterised as "the epitome of Americana", and once a very successful hockey player. His success is thus the focus of the article, as illustrated again in example (11) by "was handed the flag". The score of the game itself is important for readers to be able to understand the success, but it is not primarily what is at stake in the article. Narrative sequences, in fact, give the context for the main point of the article, which is not, in itself, narrative. The same process appears in example (12), where the narrative clause "after a workout..." gives the context for the conversation reported in the paragraph. Context may also include the questions asked by the journalist, as in example (14), since the answers are clearly what the article focuses on, explaining why the question is placed in a subordinate clause.

6 Example (13) is particularly striking in this respect since the information contained in the subordinate clause is essential for readers to understand that the athlete is successful in her sport. Since the article focuses on the life of this athlete, this information is fundamental. Moreover, the juxtaposition of the information that the athlete knew nothing about the sport with the information that she won the silver medal creates a striking rhetorical effect that would be absent if this clause were to be deleted. Presenting information as "old" information, as if it were non essential, does not mean that the information is actually not essential to understand the events described. Presenting it as "old" information serves to highlight the fact that it is not part of the main focus of the article.

Thus, even though narration is an essential part of what journalists write since narrative sequences provide information that cannot be dispensed with if the main story is to be understood, they tend to be part of the background and are generally implicit. They are often subordinated to another element that is the main focus of the article, which is why narration may sometimes seem jumbled, with events not always related in order of occurrence. Although the general structure is not narrative, narration is nevertheless present and important, even if it remains in the background on account of the journalistic standards authors are subject to.

\section{Conclusion}

58 By focusing progressively on several textual levels, it becomes clear that narration does not form the basis of the cohesion of the articles since their progression cannot be characterised as narrative. However, narration is present at a lower, syntactic level. The main question this paper sought to address was whether journalists tell stories. It would appear they do, but mainly in an implicit mode.

9 Journalists are required to respect a certain number of constraints relative to what can or cannot be said (ethical constraints related to the publication's image), with how articles are supposed to be written (structural constraints) and with what readers would like to read (economic constraints, which encourage the telling of attractive stories). Because they have to respect these guidelines, they produce a narrative that is specific to this genre, as, for example, the non-resolution that characterises press texts and their lack of a conclusion, as identified by Revaz (2009).

60 In this context, we also note that journalists produce a non-continuous narrative that is constantly interrupted by references to the future or to the present. Although these 
interruptions may be considered as part of the natural topical development of press articles, they represent digressions in the narration of a past event that may be expected from such texts. Journalists thus produce a narrative whose progression is not chronological, but which is nevertheless cohesive because the subject that is developed is expanded on consistently. In the end, although narration is clearly present in the articles, it is not foregrounded, since the activity of telling stories, in the traditional sense of the word, is not considered central to a journalist's activity. A larger-scale analysis of speech modes in press articles would make it possible to confirm the results of this exploratory study.

\section{BIBLIOGRAPHY}

ADAM Jean-Michel (2011), Les textes : types et prototypes ( $3^{\text {rd }}$ ed.), Paris: Armand Colin.

BARTHES Roland (1966), “Introduction à l'analyse structurale des récits”, Communications 8, Recherches sémiologiques : l'analyse structurale du récit, 1-27, <http://www.persee.fr/web/revues/ home/prescript/article/comm_0588-8018_1966_num_8_1_1113>.

BELCHER Diane (2004), “Trends in teaching English for specific purposes”, Annual Review of Applied Linguistics, 24, Cambridge University Press, <http://dx.doi.org/10.1017/S026719050400008X>. ELLIS Barbara (2001), The copy-editing and headline handbook, New York: Basic Books.

GENETTE Gérard (1966) “Frontières du récit”, Communications 8, Recherches sémiologiques : l'analyse structurale du récit, 152-163, <http://www.persee.fr/web/revues/home/prescript/article/ comm_0588-8018_1966_num_8_1_1121>.

GENETTE Gérard (2007), Discours du récit, Paris: Seuil.

HARTSOCK John C (2007), “It was a dark and stormy night”, Prose Studies, 29(2), 257-284, <http:// dx.doi.org/10.1080/01440350701432853>.

JOHNSTON Jane \& GRAHAM Caroline (2012), “The New, Old Journalism, Narrative writing in contemporary newspapers", Journalism Studies, 13(4), 517-533, <http://

dx.doi.org/10.1080/1461670X.2011.629803>.

KRAMER Mark (2000), “Narrative journalism comes of age”, Nieman Reports, Cambridge 54(3), 4-8.

LAFFONT Hélène \& PETIT Michel (2007), “Presse et anglais de spécialité : quelques éléments de caractérisation de la presse professionnelle", Cahiers de L'APLIUT, XXVI (3), 26-41.

LOoCK Rudy (2007), "Appositive relative clauses and their function in discourse”, Journal of Pragmatics, 39, 336-362.

NEVEU Erik (2014), “Revisiting Narrative Journalism as One of The Futures of Journalism”, Journalism Studies, 15(5), 533-542, <http://dx.doi.org/10.1080/1461670X.2014.885683>.

PÉLISSIER Nicolas \& EYRIÈS Alexandre (2014), “Fictions du réel : le journalisme narratif" Cahiers de Narratologie, 26, <http://narratologie.revues.org/6852>. 
PEYNAUD Caroline (2013), Contribution à la caractérisation de la presse écrite américaine comme domaine spécialisé : milieu, culture et discours (thèse de doctorat), Université Paris Sorbonne, Paris (13 novembre 2013).

PEYNAUD Caroline (2015), “Les mots du journalisme : de la terminologie à la culture professionnelle”, ASp, 68, 25-43.

RAMONET Ignacio (2011), L'explosion du journalisme : des médias de masse à la masse des medias, Paris : Galilée, l'Espace Critique.

RESCHE Catherine (2013), Economic Terms and Beyond: Capitalising on the Wealth of Notions, 176, Linguistic Insights, Bern: Peter Lang.

REVAZ Françoise (2009), Introduction à la narratologie, action et narration, Bruxelles: De Boeck.

ROEH Itzhak (1989), “Journalism as storytelling, coverage as narrative”, American behavioural scientist, 33(2), 162-168.

RUSSO Tracy Callaway (1998), "What is journalism?: Professional identity and ideology of journalists reconsidered", Management Communication Quarterly, 12(1), 72-111.

SARTRE Jean-Paul (1947), Situations I, Paris: Gallimard.

\section{PRIMARY SOURCES}

ALMASY Steve (2016), "Olympics hero Craig to auction 'Miracle on Ice' gold medal”, published on CNN [May $18^{\text {th }}, 2016$. Retrieved on May $\left.20^{\text {th }}, 2016\right]$ (F2).

BALDWIN Alan (2016), "Dutch couple see Olympics from one extreme to another", published on Reuters [May $19^{\text {th }}, 2016$. Retrieved on May $20^{\text {th }}, 2016$ ] (F12).

CHICAGO TRIBUNE (2016), Olympic Gold medalist Simone Biles works the crowd-and gate-at O'Hare [October $10^{\text {th }}, 2016$. Retrieved on October $11^{\text {th }}, 2016$ ] (F14).

DIAZ George (2016), "Special Olympics competitor finds light in darkness surrounding her", published on Orlando Sentinel [May $20^{\text {th }}, 2016$. Retrieved on May $20^{\text {th }}, 2016$ ] (F4).

DIMEGLIo Steve (2016), “Golfer Sergio Garcia can't wait to play in Rio Olympics”, published on USA Today [May $17^{\text {th }}, 2016$. Retrieved on May $\left.20^{\text {th }}, 2016\right]$ (F6).

FOX NEWS (2016), USA Swimming moves pre-Olympic camp from Puerto Rico over Zika concerns [May $20^{\text {th }}$ , 2016. Retrieved on May 20 $\left.0^{\text {th }}, 2016\right]$ (HN9).

HUfFInGTON POST (2016), Four Paralympians Just Ran The 1500m Faster Than Anyone At The Rio Olympics Final [September $12^{\text {th }}, 2016$. Retrieved on October $11^{\text {th }}, 2016$ ] (HN27).

NIYO John (2016), "Michigan athletes weigh risks at Rio Olympics”, published on The Detroit News [June $6^{\text {th }}, 2016$. Retrieved on June $6^{\text {th }}, 2016$ ] (HN6).

SEATTLE TIMES (2016), 13 former Washington rowers qualified to compete in Rio Olympics [May $24^{\text {th }}, 2016$. Retrieved on May $\left.25^{\text {th }}, 2016\right]$ (HN14).

SPUTNIK (2016), Summer Olympics Boost Unlikely to Solve Brazil's Deepening Economic Issues [May $16^{\text {th }}$, 2016. Retrieved on May $\left.18^{\text {th }}, 2016\right]$ (HN17).

USA TODAY (2016), Gray could become 1st US woman to win Olympic wrestling gold [May 19 $19^{\text {th }}, 2016$. Retrieved on May $\left.20^{\text {th }}, 2016\right]$ (F7).

WHARTON David (2016), “Zika virus should not stop Olympics in Rio de Janeiro, health official says", published on Los Angeles Times [May 17th, 2016. Retrieved on May $18^{\text {th }}, 2016$ ] (HN11). 


\section{NOTES}

1. My translation.

2. "fiction du reel". (My translation)

3. The exclusion of opinion pieces brings the total number of articles in the corpus to 48 .

4. For each example, the reference of the article (here, F4) indicates whether the article is feature or hard news.

5. My emphases.

6. Table 6 presents extracts from HN1: <https://www.bostonglobe.com/sports/specials/ olympics/2016/06/05/crime-casts-shadow-rio- olympics/OkSsfDPQw0Jlihu48MVgXJ/story.html> (06/06/2016).

\section{ABSTRACTS}

Journalists produce non-fictional texts about the events of the world which are meant to inform readers, be as factual as possible and give them keys to understanding the event. This orientation does not mean narration is absent from press articles; on the contrary, stories are at the heart of journalists' daily work. This study of how narration is expressed in samples of the US press illustrates how journalists find a balance between narrating facts and building attractive stories.

The analysis is based on a 35 0000-word press corpus dealing with the 2016 Rio Olympic Games. The structure of the articles is first analysed and compared to more traditional narratives, leading to a preliminary conclusion that the press articles of our corpus are not clearly built as narratives. A finer study of narrative sequences is then conducted and shows that narration is present in press articles, but only as background information.

Les journalistes produisent des textes non fictionnels qui traitent des événements du monde. Ces textes doivent informer les lecteurs, rester aussi factuels que possible et leur fournir des clés pour comprendre les événements. Cette orientation ne signifie pas que la narration est absente des articles. Au contraire, les journalistes utilisent le terme stories pour les articles qu'ils rédigent quotidiennement. Cette étude de la façon dont le récit s'exprime dans un échantillon de la presse des États-Unis illustre la manière dont les journalistes trouvent un équilibre entre l'exposé des faits et la construction de récits attractifs.

Cette analyse se fonde sur un corpus de presse de 35000 mots portant sur les Jeux Olympiques de Rio de 2016. Dans un premier temps, la structure des articles est analysée et comparée à des récits plus traditionnels, ce qui conduit à la conclusion que les articles de presse ne sont pas clairement construits comme des récits. Une étude plus fine des séquences narratives est ensuite réalisée. Elle met en évidence que la narration est présente dans les articles de presse, mais uniquement en arrière-plan informationnel. 
INDEX

Keywords: narration, journalism, ESP, specialised varieties of English, discourse analysis, Rio Olympics

Mots-clés: narration, journalisme, anglais de spécialité, variétés spécialisées de l'anglais, analyse du discours, Jeux Olympiques de Rio

\section{AUTHOR}

CAROLINE PEYNAUD

Université Grenoble Alpes 